\title{
Characterization of Orchard Fields Based on Soil Fertility Index (SOFIX)
}

\author{
Pitchayapa Pholkaw1, Quoc Thinh Tran', Takamitsu Kai1,2, Taiki Kawagoe1, Kenzo Kubota1, \\ Kiwako S. Araki ${ }^{1}$, Motoki Kubo' ${ }^{*}$
}

${ }^{1}$ Department of Biotechnology, Faculty of Life Sciences, Ritsumeikan University, Kusatsu, Japan

${ }^{2}$ Kurokawa Field Science Center, Meiji University, Kawasaki, Japan

Email: ^kubo@sk.ritsumei.ac.jp

How to cite this paper: Pholkaw, P., Tran, Q.T., Kai, T., Kawagoe, T., Kubota, K., Araki, K.S. and Kubo, M. (2020) Characterization of Orchard Fields Based on Soil Fertility Index (SOFIX). Journal of Agricultural Chemistry and Environment, 9, 159-176.

https://doi.org/10.4236/jacen.2020.93014

Received: May 16, 2020

Accepted: August 22, 2020

Published: August 25, 2020

Copyright ( 2020 by author(s) and Scientific Research Publishing Inc. This work is licensed under the Creative Commons Attribution International License (CC BY 4.0).

http://creativecommons.org/licenses/by/4.0/ (c) (i) Open Access

\begin{abstract}
Soil samples from 139 agricultural orchard fields (apple, grape, tea, and others) were analyzed using the soil fertility index. From these samples, an orchard field database was constructed and the soil properties between orchard, upland, and paddy fields were compared. The average value of bacterial biomass in the orchard fields was $7.4 \times 10^{8}$ cells/g-soil, ranging from not detected (lower than $6.6 \times 10^{6}$ cells/g-soil) to $7.7 \times 10^{9}$ cells $/ g$-soil. The average values of total carbon (TC), total nitrogen (TN), total phosphorus (TP), and total potassium (TK), were $24,000 \mathrm{mg} / \mathrm{kg}$ (2670 to $128,100 \mathrm{mg} / \mathrm{kg}$ ), $1460 \mathrm{mg} / \mathrm{kg}$ (133 to $6400 \mathrm{mg} / \mathrm{kg}$ ), $1030 \mathrm{mg} / \mathrm{kg}$ (142 to $5362 \mathrm{mg} / \mathrm{kg}$ ), and $5370 \mathrm{mg} / \mathrm{kg}(1214$ to $18,155 \mathrm{mg} / \mathrm{kg}$ ), respectively. The $\mathrm{C} / \mathrm{N}$ and $\mathrm{C} / \mathrm{P}$ ratios were 19 (3 to 85 ) and 27 (2 to 101), respectively. Soil properties of the orchard fields were compared with those of the upland and the paddy fields. The average value of bacterial biomass in the orchard fields was almost the same as that in the upland fields $\left(8.0 \times 10^{8}\right.$ cells/g-soil), but the number was lower than that in the paddy fields $\left(12.9 \times 10^{8}\right.$ cells/g-soil). The average values of TC and TN in the orchard fields fell between those in the upland fields (TC: $33,120 \mathrm{mg} / \mathrm{kg}$, TN: $2010 \mathrm{mg} / \mathrm{kg}$ ) and the paddy fields (TC: $15,420 \mathrm{mg} / \mathrm{kg}$, TN: $1080 \mathrm{mg} / \mathrm{kg}$ ). The relationship between the bacterial biomass and TC in the orchard fields resembled that in the upland fields. A suitable soil condition for the orchard fields was determined as TC: $\geq 25,000 \mathrm{mg} / \mathrm{kg}$, TN: $\geq 1500 \mathrm{mg} / \mathrm{kg}$, TP: $\geq 900$ $\mathrm{mg} / \mathrm{kg}$ and TK: $2500-10,000 \mathrm{mg} / \mathrm{kg}$. These recommended values will be effective for the improvement of the soil quality in the orchard fields by enhancing the number and activities of microorganisms.
\end{abstract}

\section{Keywords}

Orchard Field, Soil Fertility Index (SOFIX), Bacterial Biomass 


\section{Introduction}

Orchard crop cultivation is carried out under either conventional or organic agriculture systems. The development of conventional agriculture systems using chemical fertilizers and pesticides has improved crop production and agricultural activities [1] [2] [3]. Conventional agricultural systems have a higher yield of agricultural products than organic agriculture systems, and more than $98.5 \%$ of all crops are cultivated conventionally [4]. Long-term use of chemical fertilizers and pesticides has led to environmental impacts such as lower soil fertility, reduced biodiversity, and increased greenhouse gas emissions [3] [5] [6] [7]. There are growing concerns about the negative impacts generated by conventional agricultural systems [8] [9]. As a response to these concerns, organic farming systems that aim to reduce harm to the environment have been developed [10]. However, a significant obstacle in organic agricultural systems is that the agricultural product yield is lower than those from conventional agricultural systems [11] [12] [13] [14] [15].

In a previous study, a soil fertility index (SOFIX) was developed to evaluate soil fertility and the efficiency of organic agricultural systems [16]. SOFIX has been constructed considering the importance of biological, chemical, and physical soil characteristics. Following the concept of SOFIX, bacterial biomass and its activities (nitrogen and phosphorus circulation activities) are the main factors that determine soil fertility.

More than 8000 agricultural soil samples were analyzed, and the SOFIX database was constructed from these samples. The suitable soil conditions for the upland fields based on the SOFIX database are total carbon (TC) $\geq 25,000$ $\mathrm{mg} / \mathrm{kg}$, total nitrogen $(\mathrm{TN}) \geq 1500 \mathrm{mg} / \mathrm{kg}$, total phosphorus (TP) $\geq 1100 \mathrm{mg} / \mathrm{kg}$, and total potassium (TK) 2500 to $10,000 \mathrm{mg} / \mathrm{kg}$ to maintain bacterial biomass $\geq$ $6 \times 10^{8}$ cells/g-soil and their activities [16]. The suitable soil conditions for the paddy fields based on the SOFIX database are TC $\geq 20,000 \mathrm{mg} / \mathrm{kg}, \mathrm{TN} \geq 800$ $\mathrm{mg} / \mathrm{kg}$, TP $\geq 650 \mathrm{mg} / \mathrm{kg}$, and TK 2500 to $10,000 \mathrm{mg} / \mathrm{kg}$ [17]. A standard organic soil was constructed based on the SOFIX database using biomass resources. Sufficient contents of the main elements (nitrogen, phosphorus, and potassium) and abundant microbial diversity in the standard organic soil were successfully attained [18]. The environmental conditions between the upland and the paddy fields analyzed by the database were different because of differences in their respective soil environments [19].

In this study, the orchard soils were analyzed by SOFIX for the construction of the orchard database. The features and the suitable conditions of the orchard fields were determined by comparing the upland and the paddy field databases.

\section{Materials and Methods}

\subsection{Soil Samples}

Soil samples were collected from 442 agricultural fields in Japan from 2014 to 2019. The soil samples included 190 upland fields, 113 paddy fields, and 139 
orchard fields (Table 1). Soil samples were collected from five random points in each field and sieved them through a 2-mm sieve. All soil samples were analyzed within 2 weeks of sampling, and the samples were never dried.

\subsection{Analysis of Physical and Chemical Properties of Soil}

The water-holding capacity of the soil was measured using a volumetric method [20]. The following chemical properties of the soil samples were analyzed: total carbon (TC), total nitrogen (TN), total phosphorus (TP), total potassium (TK), ammonium-nitrogen $\left(\mathrm{NH}_{4}^{+}-\mathrm{N}\right)$, nitrate-nitrogen $\left(\mathrm{NO}_{3}^{-}-\mathrm{N}\right)$, water-soluble phosphorus (SP), water-soluble potassium (SK), $\mathrm{pH}$, and electrical conductivity (EC). The TC was analyzed using a TOC analyzer (Model: SSM-5000A, Shimadzu, Kyoto, Japan). The TN, TP, and TK in soil samples were analyzed by extracting soil samples using the Kjeldahl digestion method followed by the indophenol blue method [21], the molybdenum blue method [22], and atomic absorption spectrophotometry, respectively. The $\mathrm{NH}_{4}^{+}-\mathrm{N}$ and $\mathrm{NO}_{3}^{-}-\mathrm{N}$ were analyzed by extracting them from the soil samples with $1 \mathrm{M} \mathrm{KCl}$, followed by the indophenol blue method and the brucine method. To analyze SP and SK, a soil-water suspension $(1: 20, \mathrm{w} / \mathrm{v})$ was shaken reciprocally at $100 \mathrm{rpm}$ for $1 \mathrm{~h}$ and the extracts were analyzed by the molybdenum blue method and atomic absorption spectrophotometry, respectively. The $\mathrm{pH}$ and EC were determined in a 1:2.5 soil-water mixture (w/v). Soil $\mathrm{pH}$ was measured by a $\mathrm{pH}$ meter (LAQUA. F-71, Horiba, Kyoto, Japan). Soil EC was measured by an EC meter (5LE1-408, Kenis, Hyogo, Japan).

\subsection{Analysis of Biological Properties of Soil}

The bacterial biomass in the soil samples was measured by quantifying the environmental DNA (eDNA) using the slow-stirring method [23]. To extract the eDNA from the soil, a 1.0-g soil sample was mixed with $8.0 \mathrm{~mL}$ of DNA extraction buffer (100 mM tris (hydroxymethyl) aminomethane, $100 \mathrm{mM}$ sodium EDTA, $100 \mathrm{mM}$ sodium dihydrogen orthophosphate, $1.5 \mathrm{M}$ sodium chloride, $1 \%$ (w/v) hexadecyltrimethylammonium bromide), and $1.0 \mathrm{~mL}$ of $20 \%(\mathrm{w} / \mathrm{v})$ sodium dodecyl sulfate solution. The suspension was agitated with a propeller for $20 \mathrm{~min}$. The suspension was centrifuged at $5000 \times g$ for $10 \mathrm{~min}$, and then transferred about $700 \mu \mathrm{L}$ of supernatant into a $1.5 \mathrm{~mL}$ microtube and $700 \mu \mathrm{L}$ of

Table 1. Analysis of orchard fields for construction of the database.

\begin{tabular}{cc}
\hline Field type & No. of sample \\
\hline Apple & 22 \\
Grape & 22 \\
Tea & 84 \\
Others & 11 \\
Total & 139 \\
\hline
\end{tabular}


chloroform-isoamyl alcohol was slowly added. The mixture was centrifuged at $18,000 \times g$ for $10 \mathrm{~min}$ and then added $300 \mu \mathrm{L}$ of isopropanol and separated the precipitate by centrifugation at $18,000 \times g$ for $20 \mathrm{~min}$. The pellet of crude nucleic acid was dissolved in TE buffer (10 mM Tris- $\mathrm{HCl}$ and $1 \mathrm{mM}$ EDTA, $\mathrm{pH}$ 8.0) after drying. The extracted eDNA was quantified based on the intensity of the eDNA bands after electrophoresis on an agarose gel using Kodak 1D 3.6 Image Analysis Software (Kodak, CT, USA). The bacterial biomass in the soil was estimated by using the equation $\left(Y=1.70 \times 10^{8} X ; \mathrm{r}^{2}=0.96\right)$, where $Y$ and $X$ are the bacterial biomass $\mathrm{g}^{-1}$ soil and the amount of eDNA, respectively. Two indicators of microbial activities (nitrogen $(\mathrm{N})$ circulation and phosphorus $(\mathrm{P})$ circulation activities) were examined according to our previous studies, in which $\mathrm{N}$ circulation was calculated based on the values of $\mathrm{NH}_{4}^{+}$oxidation and $\mathrm{NO}_{2}^{-}$oxidation activities and bacterial biomass [16] [24].

\subsection{Statistical Analysis}

The parameters of soil properties were determined using a one-way analysis of variance (ANOVA). The differences were evaluated at the $5 \%$ significance level when significance was observed at the $P<0.05$ level.

\section{Results}

\subsection{Soil Property and Features of the Orchard Fields}

Soil samples from the orchard fields were analyzed with SOFIX. The values of biological, chemical, and physical parameters of apple, grape, tea, and other orchard fields are shown in Table 2. The averages of the bacterial biomass of apple, grape, tea, and other field types were $1.7 \times 10^{9}, 7.0 \times 10^{8}, 4.9 \times 10^{8}$, and $7.9 \times$ $10^{8}$ cells/g-soil, respectively. Bacterial biomass in apple fields was the highest, while that in the tea fields was the lowest. The higher bacterial biomass enhances nitrogen circulation. The results indicate that nitrogen circulation activity and bacterial biomass were related to each other, while phosphorus circulation activity and bacterial biomass were not.

The average values of TC in the apple, grape, tea, and other fields were 40,900 $\mathrm{mg} / \mathrm{kg}, 19,600 \mathrm{mg} / \mathrm{kg}, 21,470 \mathrm{mg} / \mathrm{kg}$, and $18,330 \mathrm{mg} / \mathrm{kg}$, respectively. The average values of TN in the apple, grape, tea, and other fields were $1900 \mathrm{mg} / \mathrm{kg}, 1710$ $\mathrm{mg} / \mathrm{kg}, 1340 \mathrm{mg} / \mathrm{kg}$, and $1080 \mathrm{mg} / \mathrm{kg}$, respectively. The apple fields had the highest TC and TN values. The water-holding capacity of the apple fields (1130 $\mathrm{ml} / \mathrm{kg}$ ) was also relatively high. The soil $\mathrm{pH}$ in the tea fields was acidic $(\mathrm{pH} 4.0)$ than those in the other fields. No significant differences for EC were detected within the apple, grape, tea, and other fields. These results indicate that TC, TN, and water-holding capacity in the soil are related to each other.

\subsection{Relationship between TC and Bacterial Biomass in the Orchard, Upland, and Paddy Fields}

The relationship between the bacterial biomass and TC in the orchard, upland, 
Table 2. Average values of biological, chemical, and physical parameters of the orchard field.

\begin{tabular}{|c|c|c|c|c|}
\hline \multirow{2}{*}{ Parameter } & \multicolumn{4}{|c|}{ Average value } \\
\hline & Apple & Grape & Tea & Others \\
\hline $\begin{array}{l}\text { Bacterial biomass } \\
\left(\times 10^{8} \text { cells/g-soil }\right)\end{array}$ & $17.0^{\mathrm{a}}( \pm 8.7)$ & $7.0^{\mathrm{b}}( \pm 15.5)$ & $4.9^{\mathrm{b}}( \pm 7.4)$ & $7.9^{\mathrm{b}}( \pm 5.3)$ \\
\hline $\begin{array}{l}\mathrm{NH}_{4}^{+} \text {oxidation rate } \\
\text { (point) }\end{array}$ & $52.6^{\mathrm{b}}( \pm 26.2)$ & $49.9^{\mathrm{b}}( \pm 32.3)$ & $76.4^{\mathrm{a}}( \pm 38.1)$ & $41.0^{\mathrm{b}}( \pm 29.5)$ \\
\hline $\begin{array}{cl}\mathrm{NO}_{2}^{-} & \text {oxidation rate } \\
& \text { (point) }\end{array}$ & $42.3^{\mathrm{ab}}( \pm 25.8)$ & $35.4^{\mathrm{b}}( \pm 26.9)$ & $41.0^{\mathrm{ab}}( \pm 44.6)$ & $56.9^{\mathrm{a}}( \pm 23.9)$ \\
\hline $\begin{array}{l}\mathrm{N} \text { circulation activity } \\
\text { (point) }\end{array}$ & $38.4^{\mathrm{a}}( \pm 20.4)$ & $20.3^{\mathrm{b}}( \pm 12.5)$ & $19.4^{\mathrm{b}}( \pm 19.6)$ & $33.8^{\mathrm{a}}( \pm 21.4)$ \\
\hline $\begin{array}{l}\text { P circulation activity } \\
\text { (point) }\end{array}$ & $1.0^{\mathrm{c}}( \pm 1.0)$ & $3.2^{\mathrm{b}}( \pm 3.0)$ & $24.7^{\mathrm{a}}( \pm 32.9)$ & $15.9^{\mathrm{a}}( \pm 12.6)$ \\
\hline $\mathrm{TC}(\mathrm{mg} / \mathrm{kg})$ & $40,900^{\mathrm{a}}( \pm 12,930)$ & $19,600^{\mathrm{b}}( \pm 14,070)$ & $21,470^{\mathrm{b}}( \pm 18,900)$ & $18,330^{\mathrm{b}}( \pm 9110)$ \\
\hline $\mathrm{TN}(\mathrm{mg} / \mathrm{kg})$ & $1900^{\mathrm{a}}( \pm 670)$ & $1710^{\mathrm{ab}}( \pm 1570)$ & $1340^{\mathrm{b}}( \pm 1210)$ & $1080^{\mathrm{b}}( \pm 260)$ \\
\hline $\mathrm{TP}(\mathrm{mg} / \mathrm{kg})$ & $1190^{\mathrm{a}}( \pm 600)$ & $820^{\mathrm{b}}( \pm 580)$ & $970^{\mathrm{ab}}( \pm 960)$ & $1550^{\mathrm{a}}( \pm 580)$ \\
\hline $\mathrm{TK}(\mathrm{mg} / \mathrm{kg})$ & $4350^{\mathrm{b}}( \pm 1710)$ & $2990^{c}( \pm 710)$ & $6240^{\mathrm{a}}( \pm 4170)$ & $5540^{\mathrm{ab}}( \pm 3730)$ \\
\hline $\mathrm{C} / \mathrm{N}$ ratio & $22^{\mathrm{a}}( \pm 4)$ & $14^{\mathrm{b}}( \pm 7)$ & $19^{\mathrm{ab}}( \pm 12)$ & $18^{\mathrm{ab}}( \pm 8)$ \\
\hline $\mathrm{C} / \mathrm{P}$ ratio & $39^{\mathrm{a}}( \pm 12)$ & $26^{\mathrm{b}}( \pm 8)$ & $26^{\mathrm{b}}( \pm 16)$ & $14^{c}( \pm 8)$ \\
\hline $\mathrm{NO}_{3}^{-}-\mathrm{N}(\mathrm{mg} / \mathrm{kg})$ & $6.2^{\mathrm{b}}( \pm 7.2)$ & $0.2^{c}( \pm 0.6)$ & $18.0^{\mathrm{a}}( \pm 10.9)$ & $11.1^{\mathrm{b}}( \pm 7.7)$ \\
\hline $\mathrm{NH}_{4}^{+}-\mathrm{N}(\mathrm{mg} / \mathrm{kg})$ & $7.0^{c}( \pm 21.3)$ & $108.1^{\mathrm{a}}( \pm 95.3)$ & $70.7^{\mathrm{b}}( \pm 59.5)$ & $1.9^{c}( \pm 1.8)$ \\
\hline Soluble $\mathrm{P}_{2} \mathrm{O}_{5}(\mathrm{mg} / \mathrm{kg})$ & $332^{\mathrm{a}}( \pm 376)$ & $372^{\mathrm{a}}( \pm 633)$ & $123^{\mathrm{b}}( \pm 249)$ & $434^{\mathrm{a}}( \pm 521)$ \\
\hline Soluble $\mathrm{K}_{2} \mathrm{O}(\mathrm{mg} / \mathrm{kg})$ & $923^{\mathrm{a}}( \pm 412)$ & $278^{\mathrm{b}}( \pm 317)$ & $110^{c}( \pm 109)$ & $244^{\mathrm{b}}( \pm 246)$ \\
\hline $\mathrm{pH}$ & $6.5^{\mathrm{a}}( \pm 0.5)$ & $6.3^{\mathrm{a}}( \pm 0.5)$ & $4.0^{\mathrm{b}}( \pm 0.8)$ & $6.5^{\mathrm{a}}( \pm 0.9)$ \\
\hline $\mathrm{EC}(\mathrm{ds} / \mathrm{m})$ & $0.3^{\mathrm{a}}( \pm 0.2)$ & $0.3^{\mathrm{a}}( \pm 0.3)$ & $0.2^{\mathrm{a}}( \pm 0.1)$ & $0.2^{\mathrm{a}}( \pm 0.1)$ \\
\hline Water content (\%) & $27^{\mathrm{a}}( \pm 11)$ & $29^{\mathrm{a}}( \pm 19)$ & $24^{\mathrm{a}}( \pm 8)$ & $19^{\mathrm{a}}( \pm 6)$ \\
\hline $\begin{array}{l}\text { Water-holding capacity } \\
\qquad(\mathrm{ml} / \mathrm{kg})\end{array}$ & $1130^{\mathrm{a}}( \pm 329)$ & $1316^{\mathrm{a}}( \pm 736)$ & $759^{\mathrm{b}}( \pm 325)$ & $577^{\mathrm{b}}( \pm 260)$ \\
\hline
\end{tabular}

Means followed by the same letter do not significantly differ $(P<0.05)$. Value followed by \pm is standard deviation.

and paddy fields were investigated. The average values of biological, chemical, and physical parameters of the three field types are shown in Table 3. The average bacterial biomass in the orchard fields $\left(7.4 \times 10^{8}\right.$ cells/g-soil) was almost the same in the upland fields $\left(8.0 \times 10^{8}\right.$ cells/g-soil $)$, but the value was lower in the paddy fields $\left(12.9 \times 10^{8}\right.$ cells/g-soil). The bacterial biomass of 90 orchard soil samples $(64.7 \%)$ was lower than $6.0 \times 10^{8}$ cells/g-soil (Figure $1(\mathrm{a})$ ). The bacterial biomass of many tea soil samples was not detected $\left(<6.6 \times 10^{6}\right.$ cells/g-soil $)$, indicating that agrochemicals use in the tea fields is relatively high. 
Table 3. Average values of biological, chemical, and physical parameters of the orchard, upland, and paddy fields.

\begin{tabular}{|c|c|c|c|}
\hline \multirow{2}{*}{ Parameter } & \multicolumn{3}{|c|}{ Average value } \\
\hline & Orchard & Upland & Paddy \\
\hline Bacterial biomass $\left(\times 10^{8}\right.$ cells $/ g$-soil $)$ & $7.4^{\mathrm{b}}( \pm 10.1)$ & $8.0^{\mathrm{b}}( \pm 9.0)$ & $12.9^{\mathrm{a}}( \pm 13.4)$ \\
\hline $\mathrm{NH}_{4}^{+}$oxidation rate (point) & $65.6^{\mathrm{a}}( \pm 37.4)$ & $40.9^{\mathrm{b}}( \pm 32.2)$ & $15.5^{\mathrm{c}}( \pm 15.5)$ \\
\hline $\mathrm{NO}_{2}^{-}$oxidation rate (point) & $41.6^{\mathrm{b}}( \pm 38.7)$ & $63.0^{\mathrm{a}}( \pm 34.4)$ & $43.6^{\mathrm{b}}( \pm 27.7)$ \\
\hline $\mathrm{N}$ circulation activity (point) & $23.7^{\mathrm{b}}( \pm 20.4)$ & $34.4^{\mathrm{a}}( \pm 30.4)$ & $21.8^{\mathrm{b}}( \pm 14.9)$ \\
\hline P circulation activity (point) & $16.8^{\mathrm{b}}( \pm 27.8)$ & $40.7^{\mathrm{a}}( \pm 37.7)$ & $36.9^{\mathrm{a}}( \pm 33.5)$ \\
\hline $\mathrm{TC}(\mathrm{mg} / \mathrm{kg})$ & $24,000^{\mathrm{b}}( \pm 18,300)$ & $33,120^{\mathrm{a}}( \pm 29,650)$ & $15,420^{c}( \pm 4910)$ \\
\hline $\mathrm{TN}(\mathrm{mg} / \mathrm{kg})$ & $1460^{\mathrm{b}}( \pm 1190)$ & $2010^{\mathrm{a}}( \pm 2580)$ & $1080^{c}( \pm 450)$ \\
\hline $\mathrm{TP}(\mathrm{mg} / \mathrm{kg})$ & $1030^{\mathrm{b}}( \pm 860)$ & $3250^{\mathrm{a}}( \pm 5300)$ & $880^{\mathrm{b}}( \pm 430)$ \\
\hline $\mathrm{TK}(\mathrm{mg} / \mathrm{kg})$ & $5370^{\mathrm{b}}( \pm 3700)$ & $8600^{\mathrm{a}}( \pm 8340)$ & $3270^{c}( \pm 1820)$ \\
\hline $\mathrm{C} / \mathrm{N}$ ratio & $19^{\mathrm{a}}( \pm 11)$ & $20^{\mathrm{a}}( \pm 16)$ & $16^{\mathrm{a}}( \pm 7)$ \\
\hline $\mathrm{C} / \mathrm{P}$ ratio & $27^{\mathrm{a}}( \pm 15)$ & $31^{\mathrm{a}}( \pm 78)$ & $24^{\mathrm{a}}( \pm 33)$ \\
\hline $\mathrm{NO}_{3}^{-}-\mathrm{N}(\mathrm{mg} / \mathrm{kg})$ & $12.8^{\mathrm{b}}( \pm 11.6)$ & $43.8^{\mathrm{a}}( \pm 123.3)$ & $5.1^{\mathrm{c}}( \pm 8.3)$ \\
\hline $\mathrm{NH}_{4}^{+}-\mathrm{N}(\mathrm{mg} / \mathrm{kg})$ & $61.1^{\mathrm{a}}( \pm 69.3)$ & $15.0^{\mathrm{b}}( \pm 36.0)$ & $8.5^{\mathrm{b}}( \pm 34.7)$ \\
\hline Soluble $\mathrm{P}_{2} \mathrm{O}_{5}(\mathrm{mg} / \mathrm{kg})$ & $220^{\mathrm{a}}( \pm 400)$ & $60^{\mathrm{b}}( \pm 80)$ & $18^{\mathrm{c}}( \pm 21)$ \\
\hline Soluble $\mathrm{K}_{2} \mathrm{O}(\mathrm{mg} / \mathrm{kg})$ & $276^{\mathrm{a}}( \pm 371)$ & $273^{\mathrm{a}}( \pm 393)$ & $43^{\mathrm{b}}( \pm 74)$ \\
\hline $\mathrm{pH}$ & $5.0^{\mathrm{b}}( \pm 1.4)$ & $6.4^{\mathrm{a}}( \pm 1.0)$ & $7.5^{\mathrm{a}}( \pm 8.4)$ \\
\hline $\mathrm{EC}(\mathrm{ds} / \mathrm{m})$ & $0.2^{\mathrm{b}}( \pm 0.2)$ & $0.9^{\mathrm{a}}( \pm 1.8)$ & $0.8^{\mathrm{a}}( \pm 1.9)$ \\
\hline Water content (\%) & $25^{c}( \pm 11)$ & $42^{\mathrm{a}}( \pm 36)$ & $33^{\mathrm{b}}( \pm 23)$ \\
\hline Water-holding capacity (ml/kg) & $891^{\mathrm{a}}( \pm 477)$ & $804^{\mathrm{a}}( \pm 947)$ & $609^{\mathrm{b}}( \pm 400)$ \\
\hline
\end{tabular}

Means followed by the same letter do not significantly differ $(P<0.05)$. Value followed by \pm is standard deviation.

The average values of TC in the orchard, upland, and paddy fields were 24,000 $\mathrm{mg} / \mathrm{kg}, 33,120 \mathrm{mg} / \mathrm{kg}$, and $15,420 \mathrm{mg} / \mathrm{kg}$, respectively. The TC value of the orchard fields was between those of the upland and paddy fields. The TC value of 50 orchard soil samples (35.9\%) was higher than $24,000 \mathrm{mg} / \mathrm{kg}$ (Figure $1(\mathrm{a})$ ), and about $50 \%$ of the upland soil samples exhibited high TC (above $25,000 \mathrm{mg} / \mathrm{kg}$ ) (Figure 1(b)). The range of TC values in the paddy fields was narrow (8000 to $25,000 \mathrm{mg} / \mathrm{kg}$ ) (Figure 1(c)).

Among the SOFIX parameters, bacterial biomass and TC are two of the most important factors that determine soil fertility. The relationships between bacterial biomass and TC in the orchard $\left(R^{2}=0.34\right)$, upland $\left(R^{2}=0.09\right)$, and paddy fields $\left(R^{2}=0.01\right)$ (Figures $\left.1(\mathrm{a})-(\mathrm{c})\right)$. The accumulation level of carbon in the orchard fields was similar to that in the upland fields, indicating that an agricultural system using biomass for organic fertilizer is reasonable. In addition, a relatively aerobic condition in both soil environments creates similar microbial diversity. 


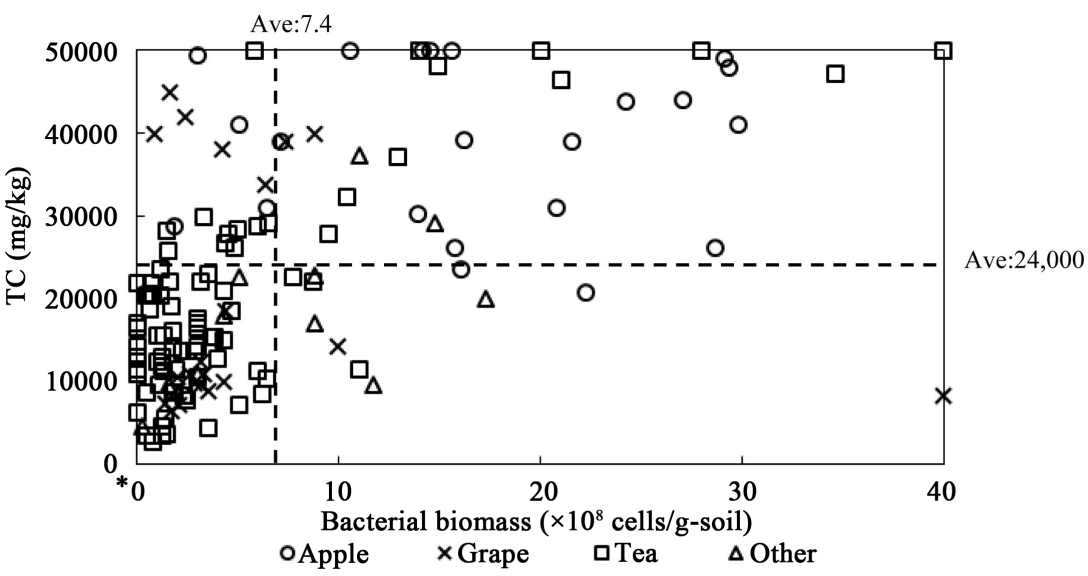

(a)

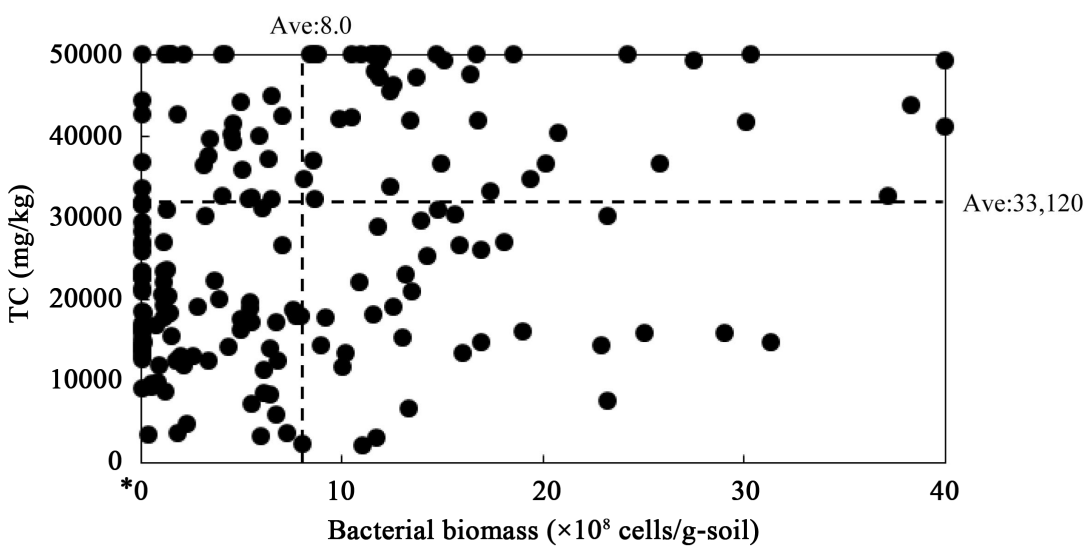

(b)

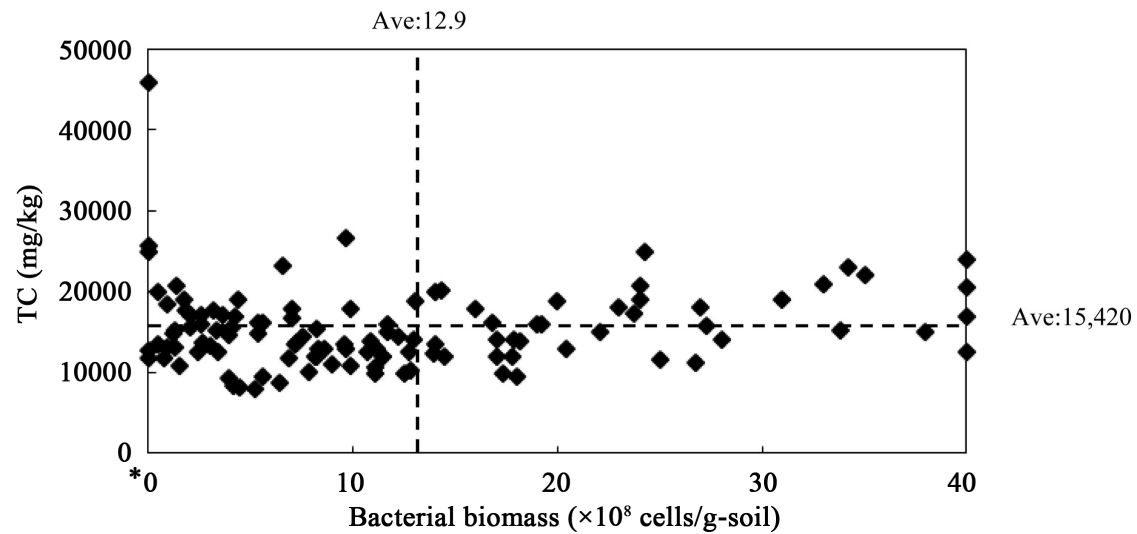

(c)

Figure 1. Relationship between TC and bacterial biomass of orchard field (a); upland field (b); and paddy field (c). Dashed lines indicate the average values of TC and bacterial biomass in each field. ${ }^{*}$ : Not detected $\left(<6.6 \times 10^{6}\right.$ cells/g-soil $)$.

\subsection{Relationship between TC and TN in the Orchard, Upland, and Paddy Fields}

Figure 2 shows the relationship between TC and TN. The average values of TN and the $\mathrm{C} / \mathrm{N}$ ratio in the orchard fields were $1460 \mathrm{mg} / \mathrm{kg}$ and 19 , respectively (Table 3 ). The average TN value in the orchard fields was lower than that in the 


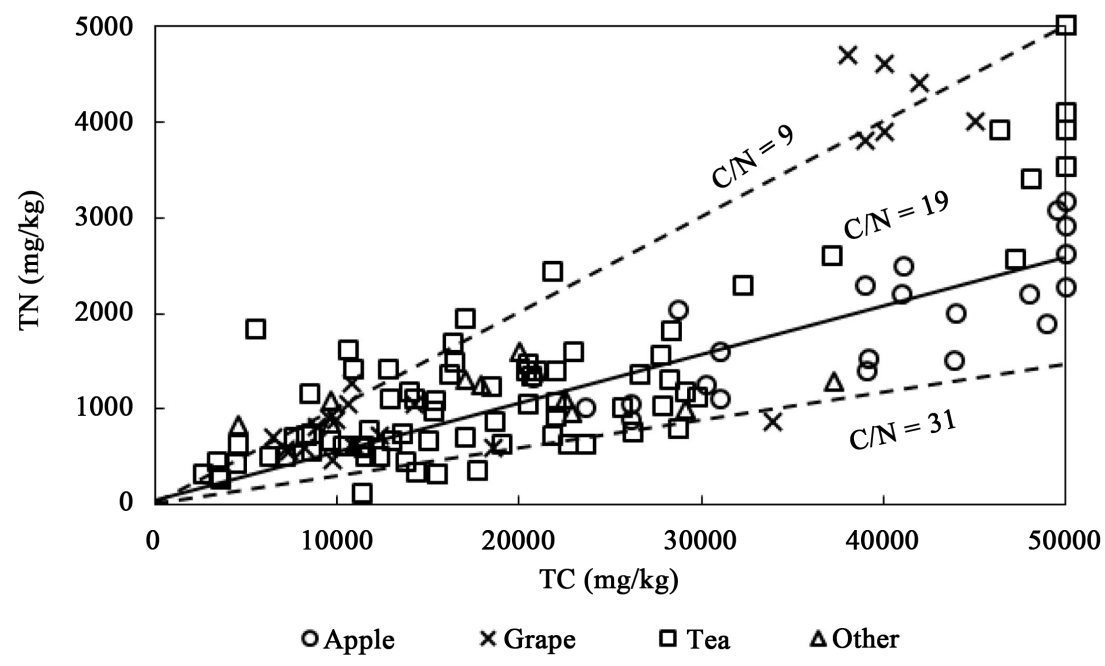

(a)

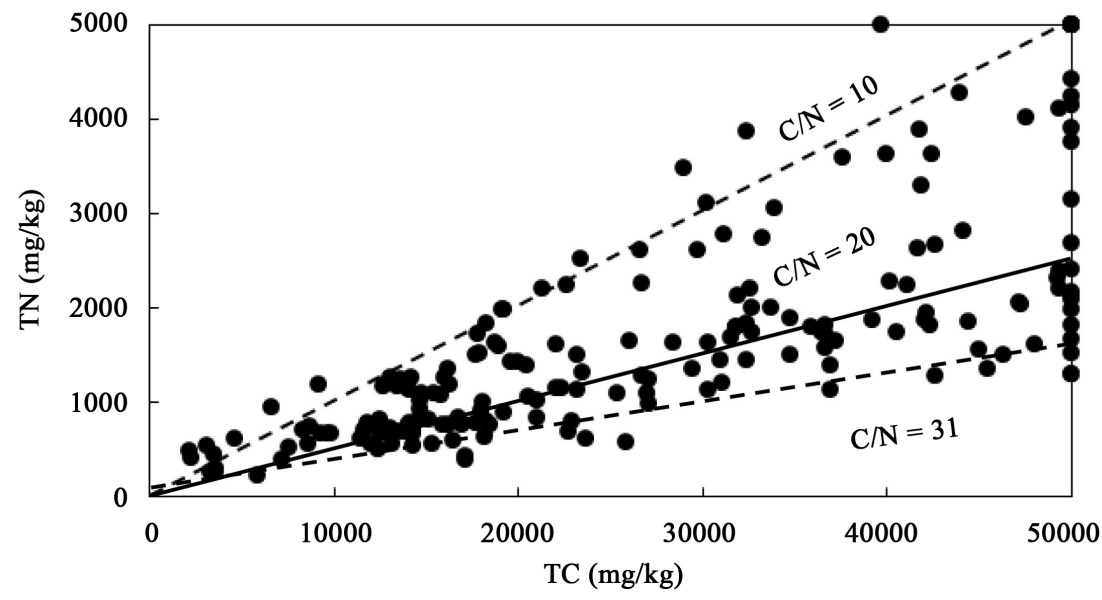

(b)

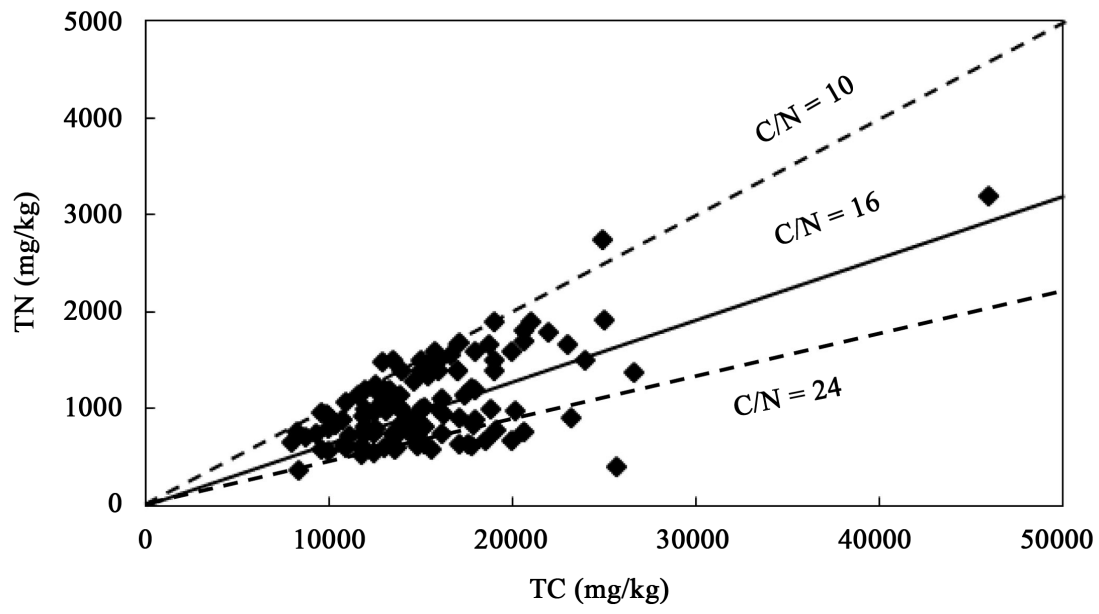

(c)

Figure 2. Relationship between TC and TN of orchard field (a); upland field (b); and paddy field (c). Solid line indicates the average values between TC and TN. Dashed lines indicate $\mathrm{C} / \mathrm{N}$ ratio of $80 \%$ of samples. 
upland fields $(2010 \mathrm{mg} / \mathrm{kg})$, but the value was higher than that in the paddy fields $(1080 \mathrm{mg} / \mathrm{kg})$. A significant positive relationships between TC and TN in the orchard $\left(R^{2}=0.64\right)$, upland $\left(R^{2}=0.55\right)$, and paddy fields $\left(R^{2}=0.45\right)$ were observed. Organic materials such as manures and unfermented materials possess a similar ratio to $\mathrm{TC}$ and $\mathrm{TN}$. This finding indicates that $\mathrm{C} / \mathrm{N}$ ratios of the orchard fields, the upland fields, and the paddy fields were resembled.

\subsection{Relationship between TC and TP in the Orchard, Upland, and Paddy Fields}

Figure 3 illustrates the relationships between TC and TP in the orchard, upland, and paddy fields. The average value of TP and C/P ratio in the orchard fields was $1030 \mathrm{mg} / \mathrm{kg}$ and 27, respectively. The average value of TP in the orchard fields was lower than that in the upland fields $(3250 \mathrm{mg} / \mathrm{kg})$, but the value was higher than that in the paddy fields $(880 \mathrm{mg} / \mathrm{kg})$ (Table 3$)$. The weak relationship between the C/P ratio in the orchard $\left(R^{2}=0.32\right)$ and the upland fields $\left(R^{2}=0.20\right)$ were observed (Figure 3(a) and Figure 3(b)). However, no relationship with the $\mathrm{C} / \mathrm{P}$ ratio in the paddy fields $\left(R^{2}=0.04\right)$ was observed (Figure $3(\mathrm{c})$ ). The relationships between TC and TP in the three field types were variable. In addition, the relationship between the $\mathrm{C} / \mathrm{P}$ ratio in the orchard and the upland fields was distributed over a wide range, while the range of the $\mathrm{C} / \mathrm{P}$ ratio in the paddy fields was narrow. This finding suggests that TC was not related with TP compared with the relationship between TC and TN.

\subsection{The Minimum and Recommended Values for the Orchard Fields}

To determine the minimum and recommended values for the orchard fields, the TC, TN, TP, and TK values were compared with the upland and paddy fields (Figures 4-7). The TC, TN, and TK levels in the orchard fields were the same as those in the upland fields but different from those in the paddy fields, while the levels of TP in the orchard and upland fields are different. This finding suggests that the minimum and recommended values of TC, TN, and TK in the orchard and upland fields should be similar. The minimum required values in the orchard fields are TC: $\geq 12,000 \mathrm{mg} / \mathrm{kg}, \mathrm{TN}: \geq 1000 \mathrm{mg} / \mathrm{kg}$, and TK: $\geq 1500 \mathrm{mg} / \mathrm{kg}$. The recommended values in the orchard fields are TC: $\geq 25,000 \mathrm{mg} / \mathrm{kg}$, TN: $\geq 1500 \mathrm{mg} / \mathrm{kg}$, and TK: 2500 to $10,000 \mathrm{mg} / \mathrm{kg}$. The minimum and recommended values of TP are: $\geq 800$ and $\geq 900 \mathrm{mg} / \mathrm{kg}$, respectively, based on bacterial biomass, $\mathrm{N}$ circulation activity, and $\mathrm{P}$ circulation activity (Tables 4-6). Table 7 summarizes the TC, TN, TP, and TK values. These values helped determine the minimum and recommended values of the orchard fields.

\section{Discussion}

Orchard trees are cultivated as a monoculture growing for many years on flat land or in mountainous areas. Plowing is an agricultural practice done several times per year after crop rotation in the upland and paddy fields [25] [26]. The 


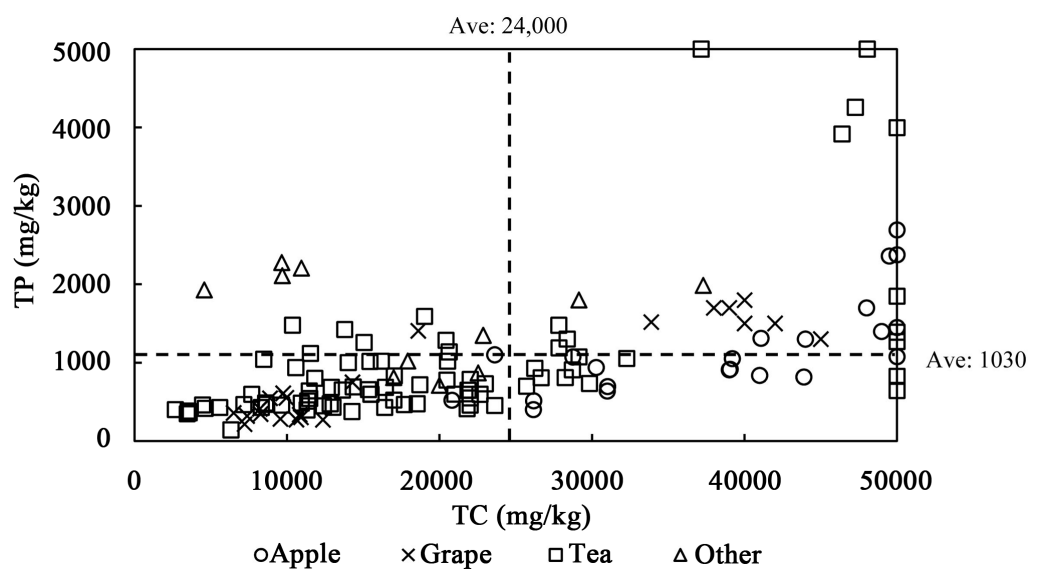

(a)

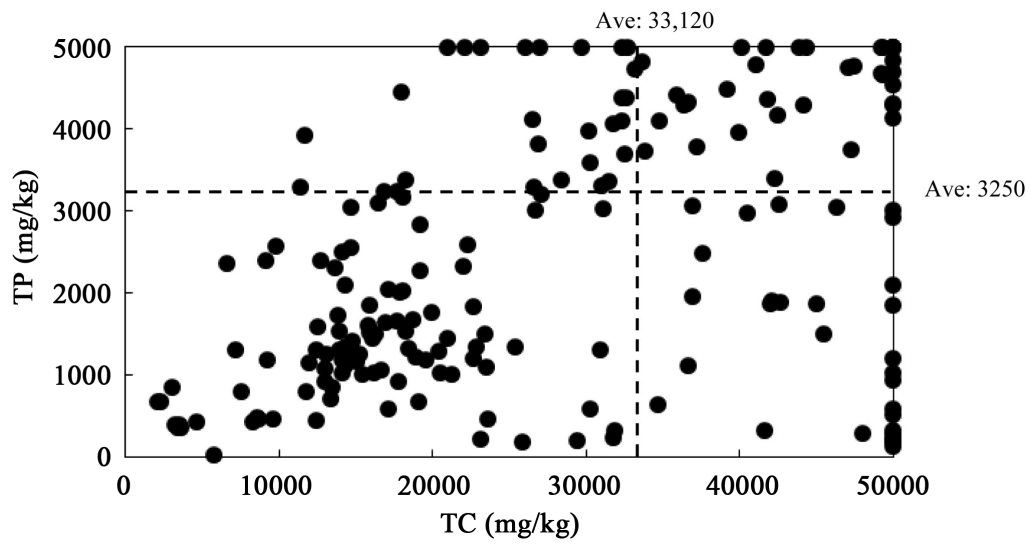

(b)

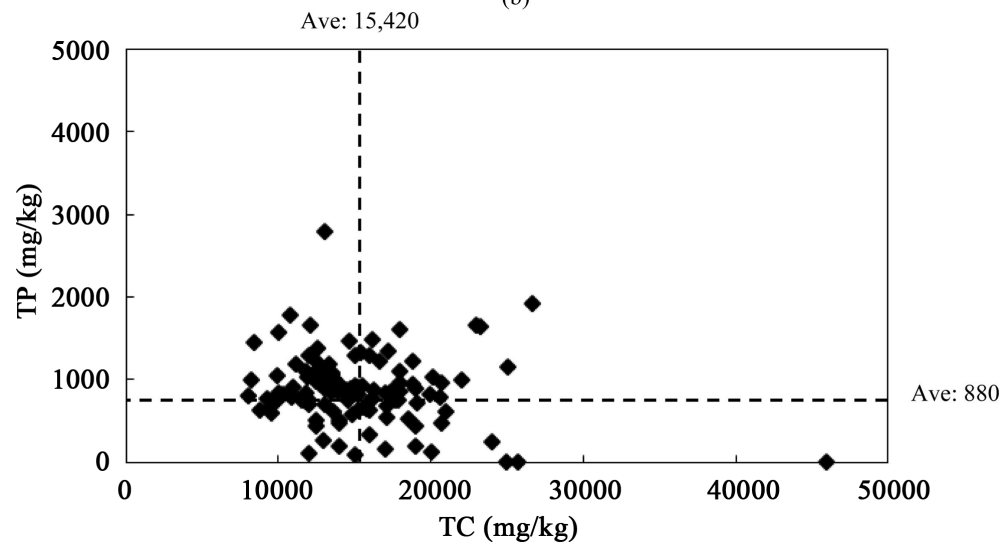

(c)

Figure 3. Relationship between TC and TP of orchard field (a); upland field (b); and paddy field (c). Dashed lines indicate the average values of TC and TP in each field.

Table 4. Average values of TC, TN, TP, and TK in each bacterial biomass ranging.

\begin{tabular}{ccccc}
\hline $\begin{array}{c}\text { Bacterial biomass } \\
\left(\times 10^{8} \text { cells/g-soil }\right)\end{array}$ & $\begin{array}{c}\mathrm{TC} \\
(\mathrm{mg} / \mathrm{kg})\end{array}$ & $\begin{array}{c}\mathrm{TN} \\
(\mathrm{mg} / \mathrm{kg})\end{array}$ & $\begin{array}{c}\mathrm{TP} \\
(\mathrm{mg} / \mathrm{kg})\end{array}$ & $\begin{array}{c}\mathrm{TK} \\
(\mathrm{mg} / \mathrm{kg})\end{array}$ \\
\hline$<2.0$ & 14,840 & 1071 & 709 & 6111 \\
$2.0-6.0$ & 20,303 & 1206 & 827 & 5366 \\
$>6.0$ & 36,582 & 2101 & 1532 & 4654 \\
\hline
\end{tabular}




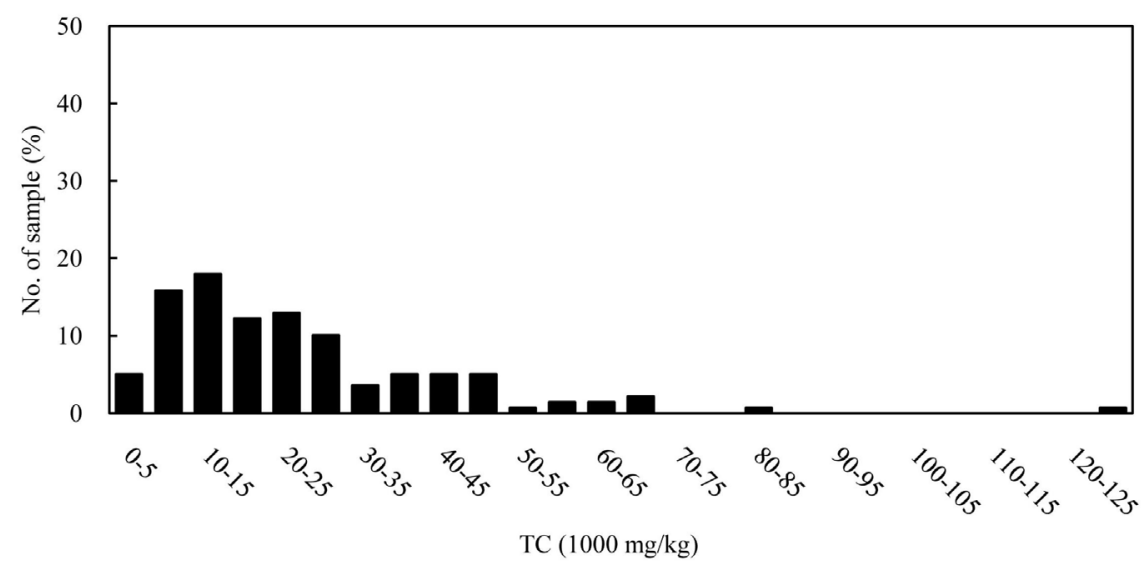

(a)

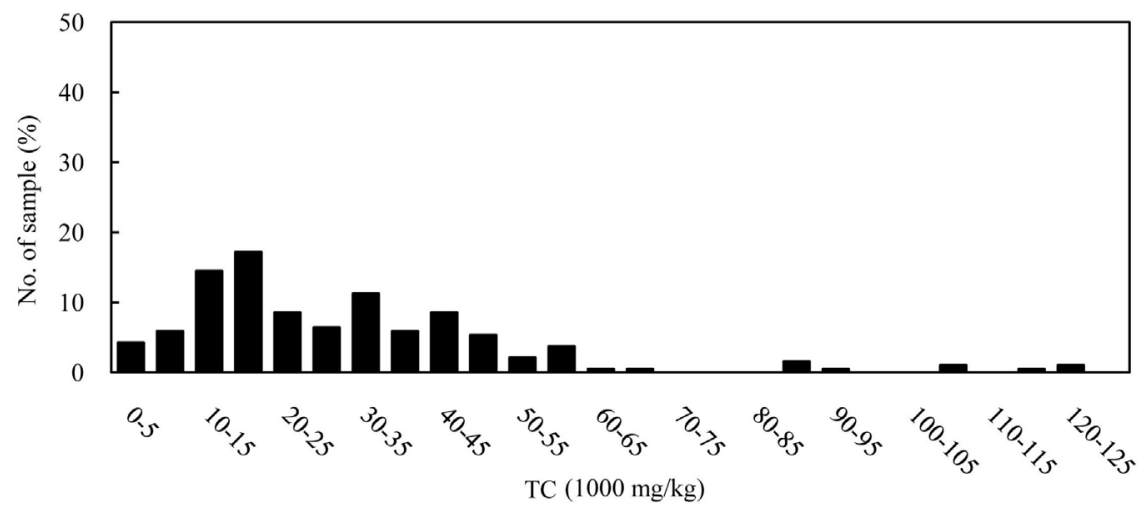

(b)

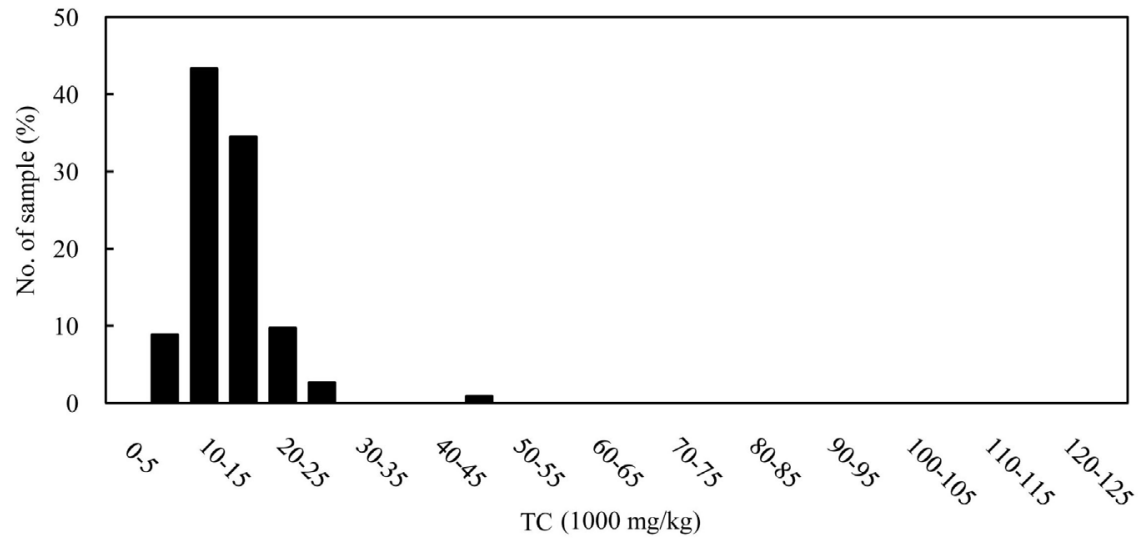

(c)

Figure 4. Frequency distribution of TC in the orchard (a); upland (b); and paddy (c) fields.

Table 5. Average values of TC, TN, TP, and TK in each $\mathrm{N}$ circulation activity ranging.

\begin{tabular}{ccccc}
\hline $\begin{array}{c}\text { N circulation activity } \\
\text { (point) }\end{array}$ & $\begin{array}{c}\mathrm{TC} \\
(\mathrm{mg} / \mathrm{kg})\end{array}$ & $\begin{array}{c}\mathrm{TN} \\
(\mathrm{mg} / \mathrm{kg})\end{array}$ & $\begin{array}{c}\mathrm{TP} \\
(\mathrm{mg} / \mathrm{kg})\end{array}$ & $\begin{array}{c}\mathrm{TK} \\
(\mathrm{mg} / \mathrm{kg})\end{array}$ \\
\hline$<20$ & 17,239 & 1080 & 826 & 5639 \\
$\geq 20$ & 32,396 & 1941 & 1274 & 5040 \\
\hline
\end{tabular}




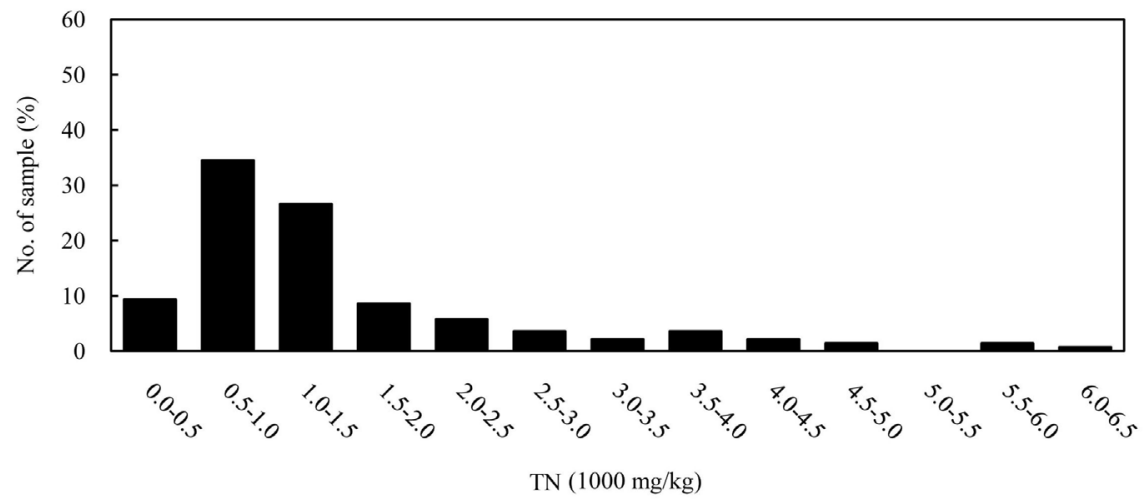

(a)

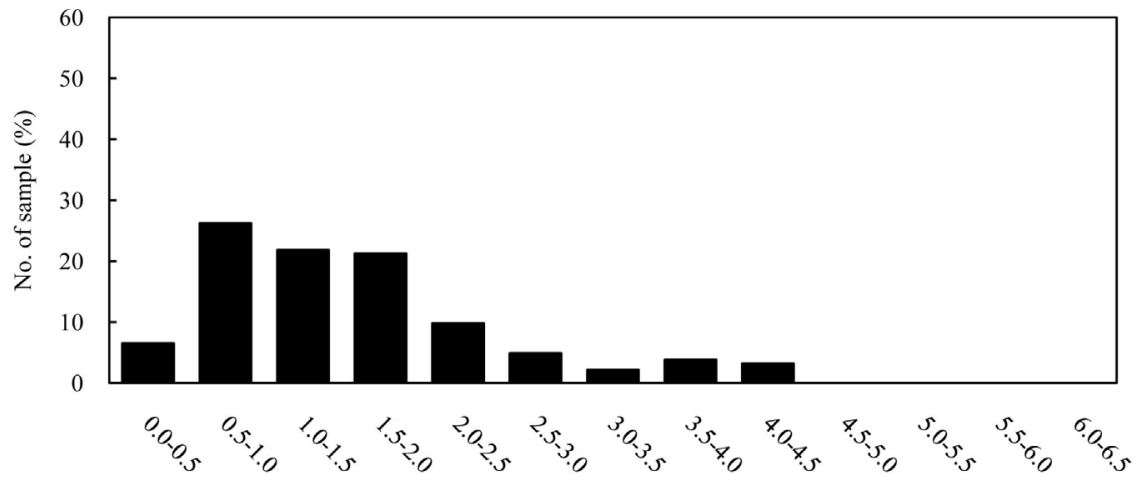

TN $(1000 \mathrm{mg} / \mathrm{kg})$

(b)

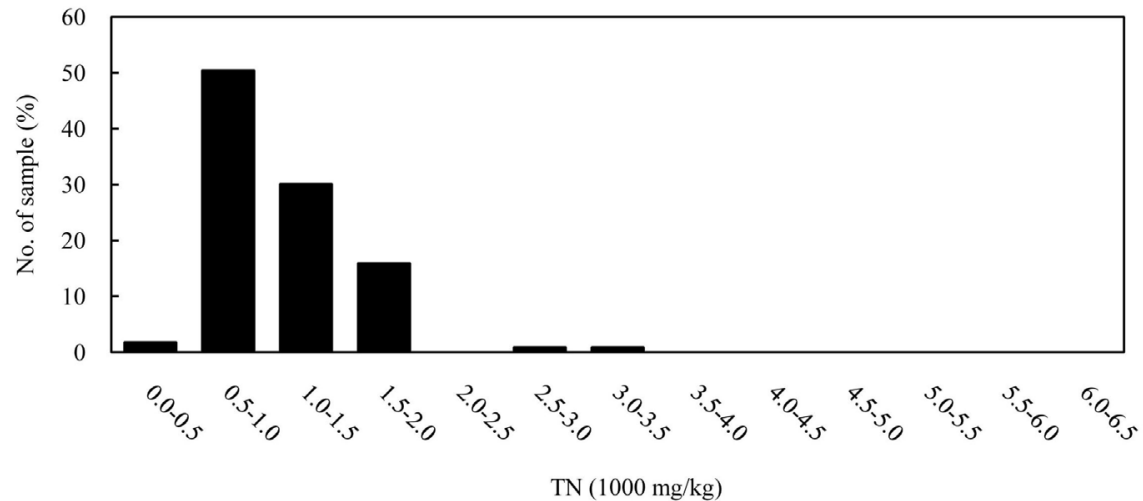

(c)

Figure 5. Frequency distribution of TN in the orchard (a); upland (b); and paddy (c) fields.

Table 6. Average values of TC, TN, TP, and TK in each $\mathrm{P}$ circulation activity ranging.

\begin{tabular}{ccccc}
\hline $\begin{array}{c}\text { P circulation activity } \\
\text { (point) }\end{array}$ & $\begin{array}{c}\mathrm{TC} \\
(\mathrm{mg} / \mathrm{kg})\end{array}$ & $\begin{array}{c}\mathrm{TN} \\
(\mathrm{mg} / \mathrm{kg})\end{array}$ & $\begin{array}{c}\mathrm{TP} \\
(\mathrm{mg} / \mathrm{kg})\end{array}$ & $\begin{array}{c}\mathrm{TK} \\
(\mathrm{mg} / \mathrm{kg})\end{array}$ \\
\hline$<20$ & 25,384 & 1528 & 1045 & 5912 \\
$20-80$ & 21,580 & 1390 & 918 & 3883 \\
$>80$ & 15,652 & 982 & 1103 & 3476 \\
\hline
\end{tabular}




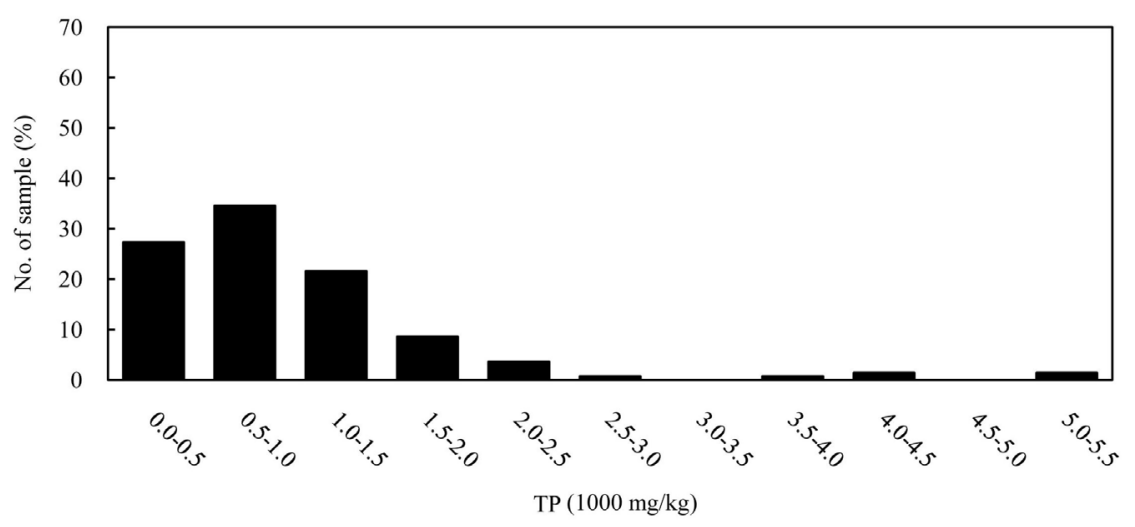

(a)

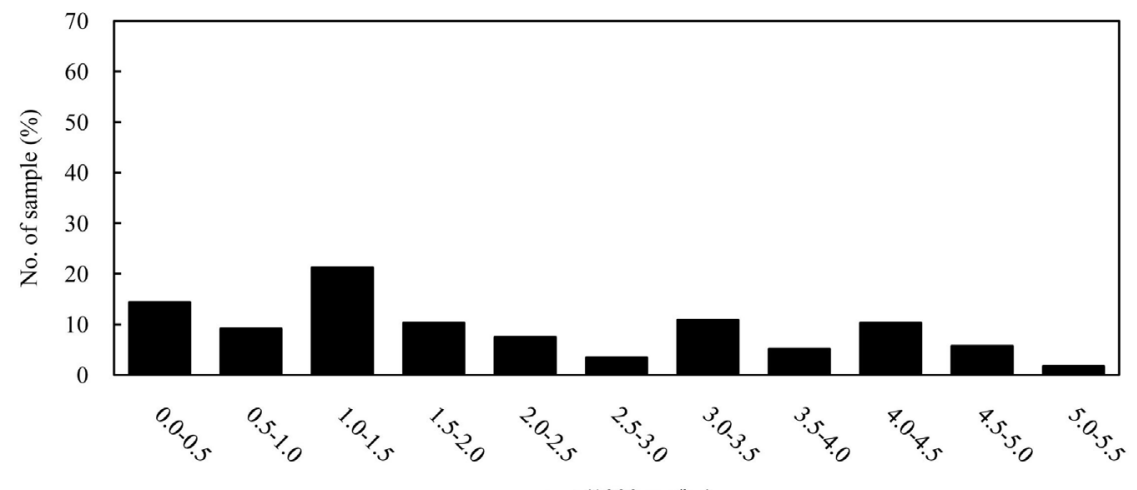

$\mathrm{TP}(1000 \mathrm{mg} / \mathrm{kg})$

(b)

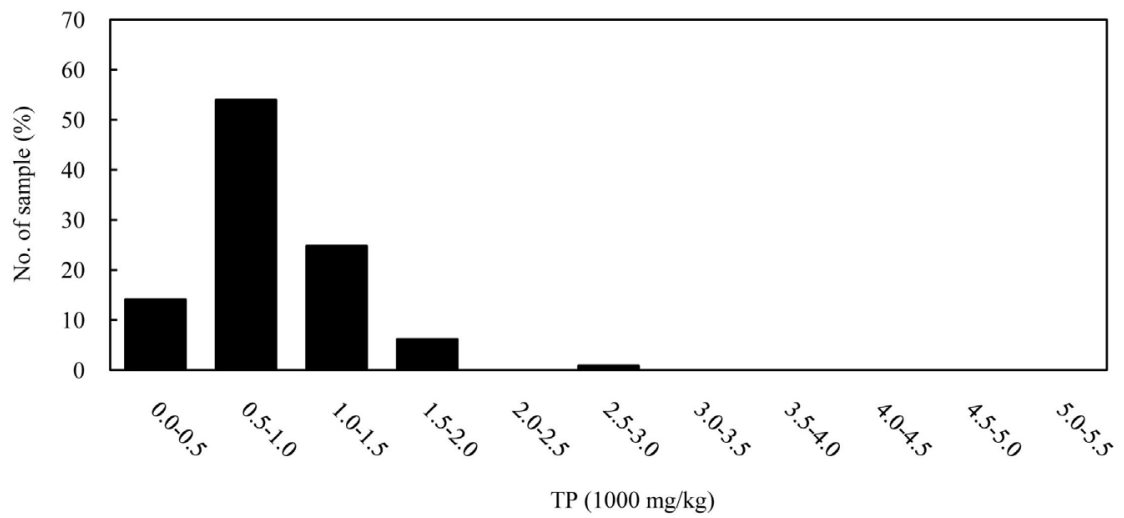

(c)

Figure 6. Frequency distribution of TP in the orchard (a); upland (b); and paddy (c) fields.

successive crops of the agricultural rotation are not typically carried out in orchard fields [27]. Plowing in the orchard fields is practiced before permanent planting to avoid damage to root systems [28].

TC, TN, TP, TK, bacterial biomass, and their activities, which are all SOFIX in parameters, are the most critical factors contributing to soil fertility. These parameters showed a similar tendency in all four orchard fields except for the lower $\mathrm{pH}$ of the soil (around $\mathrm{pH} 4.0$ ) was found in the tea fields. Generally, tea 


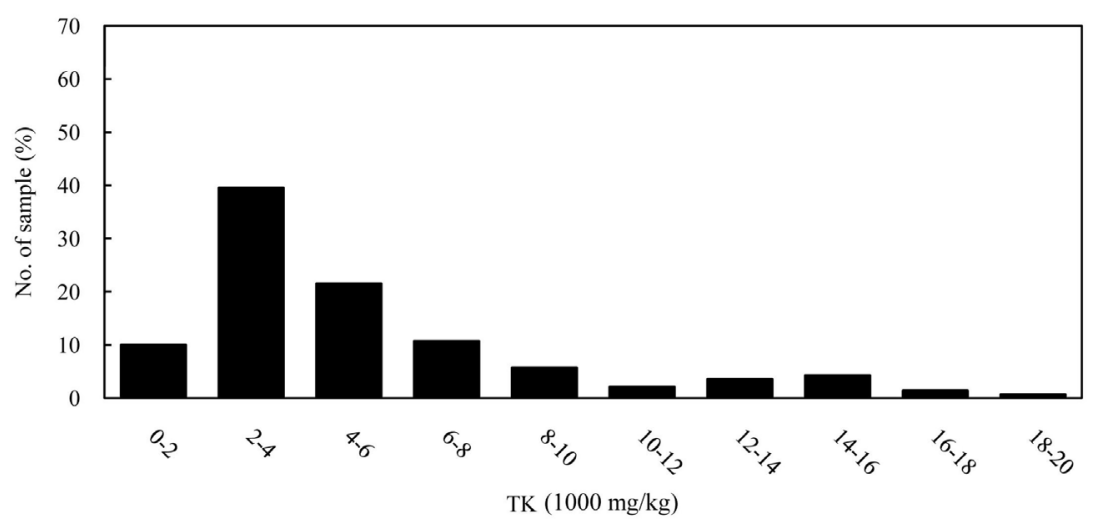

(a)

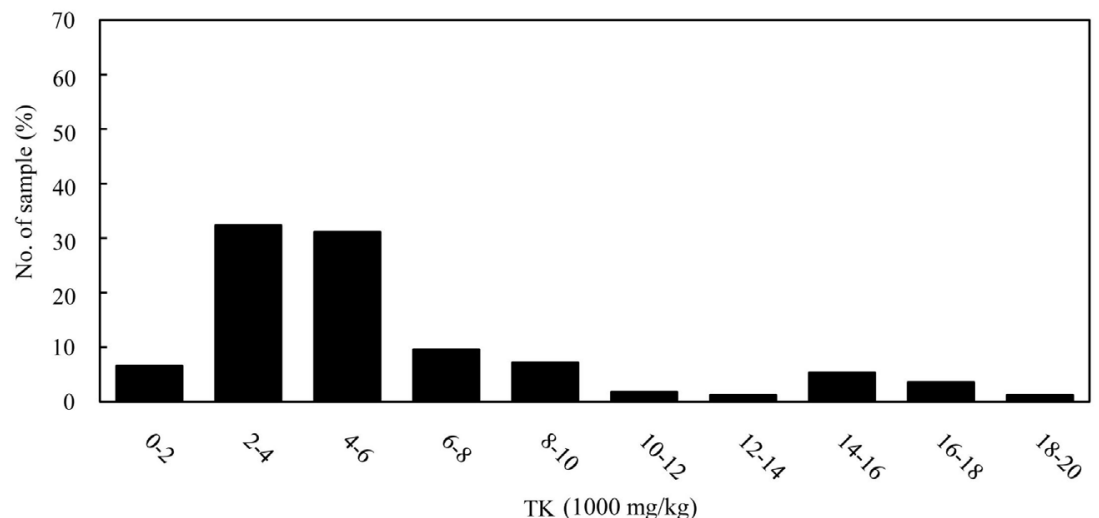

(b)

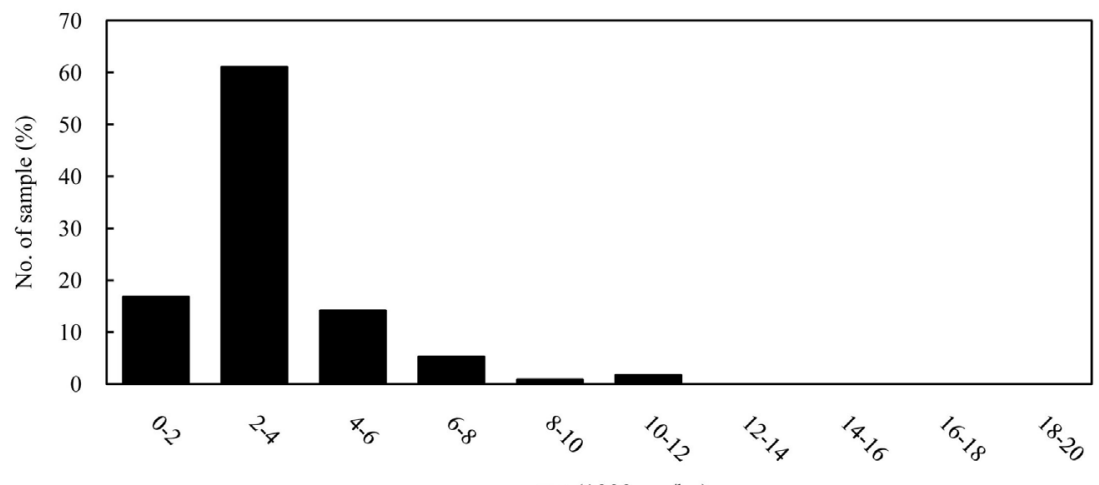

TK $(1000 \mathrm{mg} / \mathrm{kg})$

(c)

Figure 7. Frequency distribution of TK in the orchard (a); upland (b); and paddy (c) fields.

grows efficiently in an acidic soil environment, and tea is an $\mathrm{Al}$ accumulator [29]. Al biogeochemical cycling in tea leaves and fertilization in the fields over the long term leads to soil acidification in tea fields [29] [30] [31]. Additionally, tea trees prefer ammonium as a nutrient, and more $\mathrm{N}$ fertilizers are added to tea fields to increase the plant quality and yield [32] [33] [34]. Soil acidification can result from the release of $\mathrm{H}^{+}$during the process of $\mathrm{NH}_{4}^{+}-\mathrm{N}$ uptake from soil [34] [35]. 
Table 7. Minimum and recommended values of bacterial biomass, TC, TN, TP, and TK in the orchard, upland, and paddy fields.

\begin{tabular}{ccccccc}
\hline Field type & Value & $\begin{array}{c}\text { Bacterial biomass } \\
\left(\times 10^{8} \text { cells/g-soil }\right)\end{array}$ & $\begin{array}{c}\mathrm{TC} \\
(\mathrm{mg} / \mathrm{kg})\end{array}$ & $\begin{array}{c}\mathrm{TN} \\
(\mathrm{mg} / \mathrm{kg})\end{array}$ & $\begin{array}{c}\mathrm{TP} \\
(\mathrm{mg} / \mathrm{kg})\end{array}$ & $\begin{array}{c}\mathrm{TK} \\
(\mathrm{mg} / \mathrm{kg})\end{array}$ \\
\hline \multirow{2}{*}{ Orchard } & Minimum & 2.0 & $\geq 12,000$ & $\geq 1000$ & $\geq 800$ & $\geq 1500$ \\
& Recommended & 6.0 & $\geq 25,000$ & $\geq 1500$ & $\geq 900$ & $2500-10,000$ \\
\multirow{2}{*}{ Upland } & Minimum & 2.0 & $\geq 12,000$ & $\geq 1000$ & $\geq 1000$ & $\geq 1500$ \\
& Recommended & 6.0 & $\geq 25,000$ & $\geq 1500$ & $\geq 1100$ & $2500-10,000$ \\
\multirow{2}{*}{ Paddy } & Minimum & 4.5 & $\geq 13,000$ & $650-1500$ & $\geq 650$ & - \\
& Recommended & 6.0 & $\geq 20,000$ & $\geq 800$ & $\geq 650$ & $2500-10,000$ \\
\hline
\end{tabular}

Soil conditions in the orchard and upland fields were almost the same except for the accumulation of TP. The primary sources of TC and TN in the orchard fields were organic materials such as fallen leaves, wood, and organic fertilizer [36] [37]. Accumulation of TC and TN were directly proportional to each other in the orchard and the upland fields. At the same time, levels of TC and TP did not correspond, suggesting that TP-rich organic materials exist in nature (e.g., rice bran and bone meal) [18] [38]. Because TP levels in leaves and wood are relatively low, TP management in orchard fields using TP-rich organic materials is needed.

The orchard field database was constructed using 139 fields with the aims of better understanding the orchard soil features and determining suitable soil conditions. The fields used to build the database included apple, grape, tea, and other field types. The soil of the orchard fields resembles that of the upland fields; therefore, the minimum and recommended values of TC, TN, and TK were similar for both field types. Management of TC, TN, TP, TK, bacterial biomass, and their activities are critical for an organic soil environment, higher productivity, and greater quality of agricultural products in the orchard fields.

\section{Conclusion}

An orchard field database was constructed. Features of the orchard soil show that bacterial biomass, TC, and TN are related to each other. The recommended values will be effective for the improvement of the soil quality in the orchard fields by enhancing the number and activities of microorganisms.

\section{Conflicts of Interest}

The authors declare no conflicts of interest regarding the publication of this paper.

\section{References}

[1] Tilman, D., Cassman, K.G., Matson, P.A., Naylor, R. and Polasky, S. (2002) Agricultural Sustainability and Intensive Production Practices. Nature, 418, 671-677. https://doi.org/10.1038/nature01014 
[2] Seufert, V., Ramankutty, N. and Foley, J.A. (2012) Comparing the Yields of Organic and Conventional Agriculture. Nature, 485, 229-232. https://doi.org/10.1038/nature11069

[3] Matson, P.A., Parton, W.J., Power, A.G. and Swift, M.J. (1997) Agricultural Intensification and Ecosystem Properties. Science, 277, 504-509.

https://doi.org/10.1126/science.277.5325.504

[4] Willer, H., Schlatter, B., Travniek, J., Kemper, L. and Lernoud, J. (2020) The World of Organic Agriculture. Statistics and Emerging Trends 2020. Research Institute of Organic Agriculture (FiBL), Frick and IFOAM Organics International, Bonn.

[5] Singh, B.K., Kuhad, R.C., Singh, A., Lal, R. and Tripathi, K.K. (1999) Biochemical and Molecular Basis of Pesticide Degradation by Microorganisms. Critical Reviews in Biotechnology, 19, 197-225. https://doi.org/10.1080/0738-859991229242

[6] Singh, J., Singh, S., Vig, A.P., Bhat, S.A., Hundal, S.S., Yin, R. and Schädler, M. (2018) Conventional Farming Reduces the Activity of Earthworms: Assessment of Genotoxicity Test of Soil and Vermicast. Agriculture and Natural Resources, 52, 366-370. https://doi.org/10.1016/j.anres.2018.10.012

[7] Shah, F. and Wu, W. (2019) Soil and Crop Management Strategies to Ensure Higher Crop Productivity within Sustainable Environments. Sustainability Science, 11, 1-19. https://doi.org/10.3390/su11051485

[8] Tuomisto, H.L., Hodge, I.D., Riordan, P. and Macdonald, D.W. (2012) Does Organic Farming Reduce Environmental Impacts? A Meta-Analysis of European Research. Journal of Environmental Management, 112, 309-320.

https://doi.org/10.1016/j.jenvman.2012.08.018

[9] Gomiero, T., Pimentel, D. and Paoletti, M.G. (2011) Environmental Impact of Different Agricultural Management Practices: Conventional vs. Organic Agriculture. Critical Reviews in Plant Sciences, 30, 95-124. https://doi.org/10.1080/07352689.2011.554355

[10] Knapp, S. and Van der Heijden, M.G.A. (2018) A Global Meta-Analysis of Yield Stability in Organic and Conservation Agriculture. Nature Communications, 9, Article No. 3632. https://doi.org/10.1038/s41467-018-05956-1

[11] Mitchell, A.E., Hong, Y.J., Koh, E., Barrett, D.M., Bryant, D.E., Denison, R.F. and Kaffka, S. (2007) Ten-Year Comparison of the Influence of Organic and Conventional Crop Management Practices on the Content of Flavonoids in Tomatoes. Journal of Agricultural and Food Chemistry, 55, 6154-6159. https://doi.org/10.1021/jf070344+

[12] Maeder, P., Fliessbach, A., Dubois, D., Gunst, L., Fried, P. and Niggli, U. (2002) Soil Fertility and Biodiversity in Organic Farming. Science, 296, 1694-1697. https://doi.org/10.1126/science.1071148

[13] Ponti, T.D., Rijk, B. and Ittersum, M.K.V. (2012) The Crop Yield Gap between Organic and Conventional Agriculture. Agricultural Systems, 108, 1-9. https://doi.org/10.1016/j.agsy.2011.12.004

[14] Ponisio, L.C., M'gonigle, L.K., Mace, K.C., Palomino, J., Valpine, P.D. and Kremen, C. (2015) Diversification Practices Reduce Organic to Conventional Yield Gap. Proceedings of the Royal Society B: Biological Sciences, 282, 20141396.

[15] Amarante, C.V.T.D., Steffens, C.A., Mafra, Á.L. and Albuquerque, J.A. (2008) Yield and Fruit Quality of Apple from Conventional and Organic Production Systems. Pesquisa Agropecuária Brasileira, 43, 333-340. https://doi.org/10.1590/S0100-204X2008000300007

[16] Adhikari, D., Kai, T., Mukai, M., Araki, K.S. and Kubo, M. (2014) A New Proposal 
for a Soil Fertility Index (SOFIX) for Organic Agriculture and Development of a SOFIX Database for Agricultural Fields. Current Topics in Biotechnology, 8, 81-91.

[17] Motoki, K. (2017) Dojodukuri No Science. Seibumdo-Shinkosha, Tokyo, 1-191.

[18] Pholkaw, P., Muraji, A., Maeda, K., Kawagoe, T., Kubota, K., Sanpa, S., Tran, Q.T. and Kubo, M. (2019) Utilization of Wood Biomass for Organic Soil Based on the Soil Fertility Index (SOFIX). Journal of Agricultural Chemistry and Environment, 8, 224-236. https://doi.org/10.4236/jacen.2019.8417

[19] Araki, K.S., Perwira, I.Y., Adhikari, D. and Kubo, M. (2016) Comparison of Soil Properties between Upland and Paddy Fields Based on the Soil Fertility Index (SOFIX). Current Trends in Microbiology, 10, 85-94.

[20] Yargicoglu, E.N., Sadasivam, B.Y., Reddy, K.R. and Spokas, K. (2015) Physical and Chemical Characterization of Waste Wood Derived Biochars. Waste Management, 36, 256-268. https://doi.org/10.1016/j.wasman.2014.10.029

[21] Donald Nicholas, D.J. and Nason, A. (1957) Determination of Nitrate and Nitrite. Methods in Enzymology, 3, 981-984.

https://doi.org/10.1016/S0076-6879(57)03489-8

[22] Murphy, J. and Riley, J.P. (1962) A Modified Single Solution Method for the Determination of Phosphate in Natural Waters. Analytica Chimica Acta, 27, 31-36. https://doi.org/10.1016/S0003-2670(00)88444-5

[23] Aoshima, H., Kimura, A., Shibutani, A., Okada, C., Matsumiya, Y. and Kubo, M. (2006) Evaluation of Soil Bacterial Biomass Using Environmental DNA Extracted by Slow-Stirring Method. Applied Genetics and Molecular Biotechnology, 71, 875-880. https://doi.org/10.1007/s00253-005-0245-x

[24] Horii, S., Matsuno, T., Tagomori, J., Mukai, M., Adhikari, D. and Kubo, M. (2013) Isolation and Identification of Phytate-Degrading Bacteria and Their Contribution to Phytate Mineralization in Soil. The Journal of General and Applied Microbiology, 59, 353-360. https://doi.org/10.2323/jgam.59.353

[25] Takahashi, K. (1978) Soil Amendment and Fertilizer Application Improvement in Upland Fields of Red and Yellow Soils in Japan. Japan Agricultural Research Quarterly, 12, 74-78.

[26] Shinoto, Y., Matsunami, T., Otani, R. and Maruyama, S. (2018) Growth and Yield of Maize Using Two Tillage Systems in Crop Rotation of Paddy Fields. Plant Production Science, 22, 58-67. https://doi.org/10.1080/1343943X.2018.1545456

[27] Simon, S., Bouvier, J.C., Debras, J.F. and Sauphanor, B. (2010) Biodiversity and Pest Management in Orchard Systems. A Review. Agronomy for Sustainable Development, 30, 139-152. https://doi.org/10.1051/agro/2009013

[28] Huang, H. (2016) Kiwifruit the Genus Actinidia. Elsevier Inc., Amsterdam, 265-295. https://doi.org/10.1016/B978-0-12-803066-0.00007-1

[29] Alekseeva, T., Alekseev, A., Xu, R.K., Zhao, A.Z. and Kalinin, P. (2010) Effect of Soil Acidification Induced by a Tea Plantation on Chemical and Mineralogical Properties of Alfisols in Eastern China. Environmental Geochemistry and Health, 33, 137-148. https://doi.org/10.1007/s10653-010-9327-5

[30] Abe, S.S., Hashi, I., Masunaga, T., Yamamoto, S., Honna, T. and Wakatsuki, T. (2006) Soil Profile Alteration in a Brown Forest Soil under High-Input Tea Cultivation. Plant Production Science, 9, 457-461. https://doi.org/10.1626/pps.9.457

[31] Ruan, J., Ma, L. and Shi, Y. (2006) Aluminium in Tea Plantations: Mobility in Soils and Plants, and the Influence of Nitrogen Fertilization. Environmental Geochemistry and Health, 28, 519-528. https://doi.org/10.1007/s10653-006-9047-z 
[32] Oh, K., Kato, T., Li, Z.P. and Li, F.Y. (2006) Environmental Problems from Tea Cultivation in Japan and a Control Measure Using Calcium Cyanamide. Pedosphere, 16, 770-777. https://doi.org/10.1016/S1002-0160(06)60113-6

[33] Guo, J.H., Liu, X.J., Zhang, Y., Shen, J.L., Han, W.X., Zhang, W.F., Christie, P., Goulding, K.W.T., Vitousek, P.M. and Zhang, F.S. (2010) Significant Acidification in Major Chinese Croplands. Science, 327, 1008-1010. https://doi.org/10.1126/science.1182570

[34] Ruan, J., Zhang, F. and Wong, M.H. (2000) Effect of Nitrogen Form and Phosphorus Source on the Growth, Nutrient Uptake and Rhizosphere Soil Property of Camellia sinensis L. Plant and Soil, 223, 65-73. https://doi.org/10.1023/A:1004882001803

[35] Ruan, J., Ma, L., Shi, Y. and Zhang, F. (2004) Effects of Litter Incorporation and Nitrogen Fertilization on the Contents of Extractable Aluminium in the Rhizosphere Soil of Tea Plant (Camallia sinensis (L.) O. Kuntze). Plant and Soil, 263, 283-296. https://doi.org/10.1023/B:PLSO.0000047744.44940.96

[36] Kai, T., Mukai, M., Araki, K., Adhikari, D. and Kubo, M. (2016) Analysis of Chemical and Biological Soil Properties in Organically and Conventionally Fertilized Apple Orchards. Journal of Agricultural Chemistry and Environment, 5, 92-99. https://doi.org/10.4236/jacen.2016.52010

[37] Tagliavini, M., Tonon, G., Scandellari, F., Quiñones, A., Palmieri, S., Menarbin, G., Gioacchini, P. and Masia, A. (2007) Nutrient Recycling During the Decomposition of Appleleaves (Malus domestica) and Mowed Grasses in an Orchard. Agriculture, Ecosystems \& Environment, 118, 191-200. https://doi.org/10.1016/j.agee.2006.05.018

[38] Khan, M.A.I., Ueno, K., Horimoto, S., Komai, F., Tanaka, K. and Ono, Y. (2007) Evaluation of the Physio-Chemical and Microbial Properties of Green Tea Waste-Rice Bran Compost and the Effect of the Compost on Spinach Production. Plant Production Science, 10, 391-399. https://doi.org/10.1626/pps.10.391 